\title{
Analysis of Electronic Evidence as an Evidence Tools in Criminal Case Post Decision of Constitutional Court Number: 20/PUU-XVI/ 2016
}

\author{
Manshur; Rodliyah; Amiruddin \\ Faculty of Law, Mataram University, Indonesia
}

http://dx.doi.org/10.18415/ijmmu.v6i2.819

\begin{abstract}
The position of electronic evidence after the enactment of the Electronic Information and Transaction Law, in cases of criminal acts of Information and Electronic Transactions it is as separate evidence, namely electronic evidence which is an extension of the types of valid evidence stipulated in the Criminal Procedure Code while in cases outside criminal acts of Information and Electronic Transactions, electronic evidence is only located as evidence. The strength of evidence from electronic evidence obtained is not in the context of law enforcement and not at the request of law enforcement officials after the decision of the Constitutional Court Number 20/PUU-XIV/2016 is not having the power of proof both as evidence and evidence except electronic evidence that is public.
\end{abstract}

Keywords: Electronic Evidence; Constitutional Court Decision; Evidence

\section{Introduction}

The development of information and communication technology has positive and negative influences, like a double-edged sword. The use of information and communication technology on one hand contributes to the improvement of human welfare and civilization. On the other hand, advances in information and communication technology can be used to carry out acts that are against the law, which attack various legal interests of people, society and the state. ${ }^{1}$

On the one hand, the law can always keep up with the times and technology, it needs legal recognition of various types of digital technology developments to function as evidence in court. However, on the other hand the tendency to manipulate the use of digital evidence by irresponsible parties causes the law to not be free to recognize the digital evidence. ${ }^{2}$

There is a reality in the enforcement of criminal law with the emergence of new evidence not referred to in the Criminal Procedure Code but formulated as evidence in Law Number 11 of 2008 concerning Information and Electronic Transactions in the form of electronic evidence as an impact of the development of information and communication technologies that are considered more effective to reveal

\footnotetext{
1 Adami Chazawi \& Ardi Ferdian, Tindak Pidana Informasi dan Transaksi Elektronik, Media Nusa Creative, Malang, 2015, hlm.2.

${ }^{2}$ Munir Fuady,Teori Hukum Pembuktian, Citra Adiyta Bakti, Bandung, 2012, hlm. 151.
} 
a truth in the judiciary, requires an interpretation of the validity and strength of proof of electronic evidence, especially with the decision of the Constitutional Court No. 20 / PUU-XIV / 2016 dated September 7, 2016 concerning the testing of Article 5 paragraph (1) and (2) and Article 44 of the Electronic Information and Transaction Law on the 1945 Constitution proposed by Drs. Setya Novanto as the Petitioner who was motivated by an investigation by the Attorney General's Office regarding the alleged conspiracy to commit criminal acts of corruption in the contract extension of PT. Freeport Indonesia or the popular one appears with the case of " papa minta saham ", which starts from the circulation of recordings of talks between Drs. Setya Novanto together with M. Rizal Khalid and Maroef Sjamsoedin (President Director of PT. Freeport Indonesia).

Electronic evidence in the form of recording conversations in the "papa minta saham " case can it be used as a valid evidence in a criminal case is relevant for review and analysis after the Constitutional Court decision No. 20 / PUU-XVI / 2016 dated September 7, 2016 which states that Electronic Information / Electronic Documents as evidence as long as it is carried out in the context of law enforcement at the request of the police, prosecutors, and/or other law enforcement institutions stipulated by law as specified in Article 31 paragraph (3) Law Number 11 Year 2008 concerning Information and Electronic Transactions. The study and analysis of electronic evidence in the "Papa Request Stock" case was important because the initial evidence on which the Attorney General's inquiry was based was a record of the conversation between Setya Novanto and M Rizal Chalid and Syamsuddin Maaruf (President Director of PT. Freeport Indonesia) carried out quietly without permission from the recorded party.

Drs. Setya Novanto considers that the recording of the conversation between him and M Rizal Chalid and Syamsuddin Maaruf (Managing Director of PT. Freeport Indonesia) is illegal or illegal then submits a judicial review of Article 5 paragraph (1) and (2) and Article 44 The Electronic Information and Transaction Law on the 1945 Constitution to the Constitutional Court and has been decided by the Constitutional Court with the decision Number 20 / PUU-XIV / 2016 dated September 7, 2016 stating that one of his guests stated that the phrase "electronic information and / or electronic data "in Article 5 paragraph (1) and (2) and Article 44 of the Electronic Information and Transaction Law that contravene the 1945 Republic of Indonesia Constitution and do not have binding legal force insofar as it is not interpreted specifically the phrase electronic information and / or electronic data as evidence is carried out in the context of law enforcement at the request of the police, prosecutors, and / or other law enforcement institutions stipulated by law as stipulated in Article 31 paragraph (3) of the Electronic Information and Transaction Law. Based on the background described, problems can be formulated in this study, namely how is the position of electronic evidence in proving criminal cases after the enactment of Law Number 11 of 2008 concerning Information and Electronic Transactions and how the strength of evidence from electronic evidence is taken not in the framework of law enforcement at the request of law enforcement officials in the criminal court after the decision of the Constitutional Court No. 20 / PUU-XIV / 2016.

\section{Research Methods}

The type of research used is normative juridical research, in this study the author will conduct research by reviewing and analyzing various laws and regulations that regulate electronic evidence, legal principles and legal norms which become the norms or norms in proving criminal cases, in this case related to the use of electronic evidence as evidence in proving criminal cases in addition to the types of other legal evidence stipulated in the Criminal Procedure Code ${ }^{3}$. The approach method used in this study is the Statute Approach, Conceptual Approach and Case Approach Method, which is carried out by examining and studying court decisions relating to the use of electronic evidence in proof of the matter in this matter the decision of the Central Jakarta District Court in the case of premeditated murder on behalf of the defendant Jessica Kumala Wongso.

\footnotetext{
3 Amirudin \& Zainal Asikin, Pengantar Metode Penelitian Hukum, Raja Grafindo Persada, Jakarta, 2014 cetakan ke-8, hlm.167.
} 
In this study, the authors used document study techniques to collect and compile the necessary materials. Document studies are carried out using techniques to study literature books, legislation in accordance with the problem statement. The analytical method used to answer the problem formulation, namely by conducting a hermeneutic on the legislation that is the focus of research using a systematic interpretation method related to the term evidence which is listed more than once in an article or law by interpreting the provisions in legislation that is not clear about the arrangement of electronic evidence, then combined with supporting theories and conclusions drawn later.

\section{Discussion}

A. Position of Electronic Evidence in Proving a Criminal Case After the Entry into force of the Law on Information and Electronic Transactions Related to the Type of Legitimate Evidence Based on Article 184 of the Criminal Procedure Code.

The law of proving criminal cases in Indonesia as stipulated in Law Number 8 of 1981 concerning Criminal Procedure Law (KUHAP) has not formally accommodated electronic documents or information as evidence in court. Based on the provisions of Article 184 KUHAP there are 5 (five) evidences in criminal cases in Indonesia, namely witness statements, expert statements, letters, instructions and statements of the defendant. However, the laws and regulations in Indonesia are issued after the Criminal Procedure Code has regulated and acknowledged electronic evidence as a legitimate evidence, namely, among others ${ }^{4}$ :

\section{a. Law Number 8 of 1997 concerning Company Documents.}

Efforts to regulate electronic evidence have begun with the recognition of documents in the form of microfilms and other media in the field of civil law as evidence, namely in Law Number 8 of 1997 dated March 24, 1997 concerning Company Documents. Even though the Electronic Document Law has not yet formally formulated electronic documents, the definition of documents has a broader meaning, including electronic documents and not just physical documents. Article 15 of the Law on Corporate Documents is expressly acknowledged that company documents that have been published on microfilm or other media and / or their printouts are valid evidence ${ }^{5}$.

b. Law Number 31 Year 1999 juncto Law Number 20 Year 2001 concerning Amendment to Law No. 31 of 1999 concerning Eradication of Corruption Crime.

Law Number 20 Year 2001 concerning Amendment to Law Number 31 of 1999 concerning Eradication of Corruption Crime, regulates the expansion of sources of acquisition of legal evidence in the form of instructions. Based on the provisions of Article 26A of Law Number 20 Year 2001, evidence of instructions can also be obtained from other evidence in the form of information that is said, sent, received, or stored electronically with optical devices or similar but not limited to electronic connecting data (electronic data interchange), e-mail (e-mail), telegram, telex, facsimile, and from documents, namely every record of data or information that can be issued with or without the help of a facility, whether written on paper, any physical object other than paper or electronically recorded, in the form of writing, sound, images, maps, designs, photos, letters, signs, numbers, or perforations that have meaning.

\footnotetext{
${ }_{5}^{4}$ Decision of the Constitutional Court Number: 20 / PUU-XIV / 2016 dated 7 September 2016 pages 97-98.

${ }^{5}$ Sigid Suseno, Yurisdiksi Tindak Pidana Siber, Refika Aditama, Bandung, Cetakan I, 2012, hlm. 222
} 
c. Law Number 15 of 2003 concerning Determination of Government Regulation in Lieu of Law Number 1 of 2002 concerning Eradication of Criminal Acts of Terrorism becomes Law.

Law No. 15 of 2003 recognizes the existence of electronic evidence. Article 27 of Law Number 15 Year 2003 stipulates that evidence of examination of criminal acts of terrorism includes:

1. evidence as referred to in the Criminal Procedure Code;

2. other evidence in the form of information that is said, sent, received, or stored electronically with optical instruments or similar to that; and

3. data, recordings, or information that can be seen, read, and / or heard, which can be issued with or without the help of a facility, whether written on paper, any physical object other than paper, or electronically recorded, including but not limited to:

a) writing, sound, or picture;

b) maps, designs, photographs or the like;

c) letters, signs, numbers, symbols, or perforations that have meaning or can be understood by people who are able to read or understand them.

d. Law Number 15 of 2002 concerning Money Laundering Crimes which has been amended by Law Number 25 of 2003 concerning Amendments to Law Number 15 of 2002 concerning Money Laundering Crimes.

Article 38 regulating evidence in the examination of money laundering crimes includes:

a) evidence as referred to in the Criminal Procedure Code;

b) other evidence in the form of information that is said, sent, received or stored electronically with optical instruments or similar to that; and

c) documents as referred to in Article 1 number 7.

Whereas the document referred to in Article 1 number 7 is data, recordings, or information that can be seen, read, and / or heard, which can be issued with or without the help of a facility, whether written on paper, any physical object other than paper, or electronically recorded, including but not limited to:

a) writing, sound, or picture;

b) maps, designs, photos or the like;

c) letters, signs, numbers, symbols, or perforations that have meaning or can be understood by people who are able to read or understand them.

e. Law Number 21 of 2007 concerning Eradication of Crime in Trafficking in Persons.

Article 29 regulates the evidence other than as specified in the Criminal Procedure Law, can also be in the form of: 
a) Information that is said, sent, received, or stored electronically with optical instruments or similar to that; and

b) Data, recordings, or information that can be seen, read, and / or heard that can be issued with or without the help of a facility, whether written on paper, any physical object other than paper, or electronically recorded, including unlimited on:

i. writing, sound or image;

ii. maps, designs, photos or the like;

iii. letters, signs, numbers, symbols, or perforations that have meaning or can be understood by people who are able to read or understand them.

f. Law Number 8 of 2010 concerning Prevention and Eradication of Money Laundering Crimes.

Article 73 states that the legal evidence in proof of a Money Laundering crime is:

a. evidence as referred to in the Criminal Procedure Code; and/or

b. other evidence in the form of information that is said, sent, received, or stored electronically with optical instruments or similar optical devices and documents.

Whereas the documents referred to are stipulated in Article 1 number 16 which states that documents are data, recordings, or information that can be seen, read, and / or heard, which can be issued with or without the assistance of a facility, whether contained on paper or objects anything other than paper or electronically recorded, including but not limited to:

a) writing, sound, or picture;

b) maps, designs, photographs or the like;

c) letters, signs, numbers, symbols, or perforations that have meaning or can be understood by people who are able to read or understand them.

Even though Law Number 20 Year 2001, Law Number 15 Year 2003, Law Number 25 Year 2003, and Law Number 21 Year 2007, have recognized the legality of electronic information as evidence, but its application is still limited to proof criminal acts of corruption, money laundering, terrorism and only trafficking in persons. In Law Number 20 Year 2001, Law Number 15 Year 2003, Law Number 25 Year 2003, and Law Number 21 Year 2007 there is also no regulation regarding procedures or procedures that can be a reference in the acquisition and submission of electronic information and electronic documents as evidence to the court.

Although it has been regulated in a number of laws, electronic evidence is still partial and limited, because it can only be used limited in certain cases (lex specialis). The Criminal Procedure Code as a source of criminal procedure itself does not regulate electronic evidence. The legal basis for the use of electronic evidence as evidence in the judiciary became clearer after the issuance of Law Number 11 of 2008 concerning Information and Electronic Transactions.

In the Criminal Procedure Code does not regulate documents or electronic information as legal evidence. Legitimate evidence is regulated in article 184 of the Criminal Procedure Code, namely witness statements, expert statements, letters, instructions, and statements of the defendant. Of the five types of valid evidence stipulated in Article 184 of the Criminal Procedure Code, before the enactment of the Law on Information and Electronic Transactions raises problems and disagreements in classifying electronic 
evidence in the form of electronic information and documents included in what evidence. When viewed from the five types of evidence in Article 184 of the Criminal Procedure Code, special electronic evidence in the form of electronic documents (electronic mail) can only be included in the category of documentary evidence. This electronic document or e-mail is essentially an article written in an electronic form. In the Criminal Procedure Code, there is no regulation regarding electronic mail even the definition of what is meant by the letter in the general provisions of the Criminal Procedure Code is also not explained regarding electronic documents or electronic mail. This can be understood because when the KUHAP legislation process, electronic documents or electronic documents did not yet exist in the development of information technology. To determine whether electronic documents or e-mails are included in the category of documentary evidence is not easy.

The Indonesian Criminal Procedure Code adheres to a system of verification based on the law negatively (negatively wettlijke bewijs theorie), where the judge may only impose a sentence against the defendant if the evidence is limited by law and supported by a judge's conviction. Judges may not use evidence other than those legally regulated. If seen in Article 187 of the KUHAP which reads in full as follows:

"The letter as referred to in Article 184 paragraph (1) letter c, made on the oath of office or strengthened by oath, is:

a) official reports and other letters in official form made by the authorized official or made before him, which contains information about the events or circumstances that he heard, seen or experienced himself, accompanied by clear and explicit reasons regarding his statement;

b) letters made in accordance with the provisions of legislation or letters made by officials regarding matters that are included in the procedures which are their responsibility and which are intended for proof of something or circumstances;

c) a statement from an expert which contains an opinion based on his expertise regarding something or something officially requested thereof;

d) another letter that can only be valid if it has something to do with the contents of another evidentiary tool ${ }^{6}$.

From the provisions of Article 187 of the KUHAP, authentic deeds namely deeds made by and or before public officials appear in their existence in Article 187 letters a and b. For this classification, it can be called in the form of a trial report made by a substitute clerk, a call / hearing session made by a surrogate / bailiff substitute, a judge's decision, a sale and purchase deed, local inspection minutes, and so forth. Whereas for the underhanded deed, namely in the form of a certificate from an expert which contains opinions based on expertise, its existence appears in Article 187 letter c KUHAP such as post mortem et repertum, expert certificate on fingerprints (dactyloscopy), expert certificate on ballistics, expert certificate about judicial medicine, and so on. Then Article 187 letter d KUHAP, correlates with ordinary letters such as letters of reprimand, statement letter, threat letter, receipt of money receipts and so on, where the letters only have proof value if they have a close relationship with the case and are strengthened by other evidence ${ }^{7}$.

From the provisions of Article 187 letters a, b, and c above, then electronic documents or electronic mail are not included, because in Article 187 letters a, b, and c explain the letters made by and or before public officials. While electronic mail is a letter that is not made by and or before public

\footnotetext{
${ }^{6}$ Law Number 8 of 1981 concerning Criminal Procedure Law

${ }^{7}$ Lilik Mulyadi, Bunga Rampai Hukum Pidana Perspektif, Teoritis dan Praktik, Alumni, Bandung, 2008, hlm. 113
} 
officials. If the e-mail is linked to the provisions of Article 187 letter d, which is classified as an ordinary letter that has only proven power if it is related to a case, then electronic mail can be included in it. However, in the Criminal Procedure Code there is no provision that regulates electronic documents or emails included in the category of letters as referred to in Article 187 letter d, because ordinary letters differ from electronic letters which are letters made through electronic media and require further verification of the truth of the contents of electronic mail. that is.

In practice in court, the position of electronic evidence in the form of electronic documents or electronic mail prior to the enactment of Law Number 11 of 2008 concerning Information and Electronic Transactions is the same as the evidence document stipulated in Article 184 of the KUHAP because electronic documents or electronic mail are letters that in the form of electronics, so that electronic mail is included in the type of proof of letter. In the process of verification at the trial, electronic evidence in the form of documents or e-mails is not required for the original form (soft copy), which is only required to print out. This refers to Article 5 paragraph (1) of the Electronic Information and Transaction Law. Regarding the authenticity aspect of electronic printouts, the judge will ask the defendant and witness regarding the electronic mail whether there is a difference from the original form, if the defendant or victim acknowledges that the e-mail is the same as the original or there is no difference it has fulfilled the aspect of authenticity as evidence and has become a valid evidence. If one of the defendants or witnesses does not recognize it, expert information is needed to determine whether or not the print out of the document or e-mail is valid, and the expert's statement will be the basis of the judge's judgment in determining whether or not the e-mail printout is valid. as evidence in the trial.

The existence of electronic evidence in the form of electronic documents or electronic information in the legal proof system in Indonesia, actually there have been several actions that lead to the use and recognition of electronic documents as legitimate evidence, for example, by known online trading on microfilm stock exchanges and means electronics as a company document storage media regulated in Act Number 8 of 1997 concerning Company Documents.

Law Number 8 of 1997 concerning Company Documents can be said to be the beginning of regulation of electronic proof, because it has given the possibility of company documents that have been given a position as authentic written evidence, for safekeeping through storage in the form of microfilm. Furthermore, the documents stored in electronic form (paperless) can be used as valid evidence if a dispute occurs in the Court. Therefore it can be said that the emergence of the Corporate Documents Act is the starting point for recognizing electronic evidence in the form of electronic documents as evidence that can be submitted to the Court.

The birth of the Information and Electronic Transaction Law became the material basis for the existence of electronic evidence. This shows that the evidence is not only limited to what is stipulated in the Criminal Procedure Code but also evidence that is outside the KUHAP, namely electronic evidence. Materially it is very clear that this electronic evidence is recognized through the Electronic Information and Transaction Act. The problem that arises is when what is stipulated in the Criminal Procedure Code concerning the formal requirements of an evidence is applied to electronic evidence. The Electronic Information and Transaction Law as the legal basis for electronic evidence does not regulate procedures or procedures for submitting electronic evidence in the Court, so that these electronic evidence devices often do not have the strength of proof as conventional evidence in the Criminal Procedure Code.

Therefore, the electronic evidence is not used as material for consideration by the judge in making a decision, in other words the electronic evidence is considered as invalid evidence.

The regulation of electronic evidence is expressly regulated in Law Number 11 of 2008 concerning Information and Electronic Transactions. In Article 5 paragraph (1) and (2) of the Electronic Information and Transaction Law, it is stated that information and / or electronic documents and/or printed results are valid evidence and constitute an extension of legal evidence in accordance with applicable Indonesian Law . While in Article 44 of the Law on Information and Electronic Transactions, it is affirmed that the evidence of investigation, prosecution and examination in court hearings according to the provisions of this Law are as follows: 
a) evidence as referred to in statutory provisions; and

b) other evidence in the form of Electronic Information and / or Electronic Documents as referred to in Article 1 number 1 and number 4 and Article 5 paragraph (1), paragraph (2), and paragraph (3).

Provisions regarding electronic evidence in Article 5 and Article 44 of the Electronic Information and Transaction Law are special provisions (lex specialis) of the general provisions concerning legal evidence stipulated in Article 184 paragraph (1) of the Criminal Procedure Code, due to:

a. Electronic evidence extends the scope or scope of evidence provided for in the Criminal Procedure Code is proof of evidence. Printouts from Information or Electronic Documents can be categorized as other letters as referred to in Article 187 letter $\mathrm{d}$ KUHAP.

b. Electronic evidence as other evidence or adding types of valid evidence other than those stipulated in the Criminal Procedure Code that apply to 20 (twenty) types of criminal acts of Information and Electronic Transactions as regulated in the Electronic Information and Transaction Law.

c. Electronic evidence as evidence that is the source of obtaining evidence evidence other than the source of the evidence provided for in Article 188 paragraph (2) of the Criminal Procedure Code that applies to cases of general criminal offenses in addition to criminal acts of Information and Electronic Transactions and special criminal cases such as criminal cases corruption.

Therefore, in cases of criminal acts of Information and Electronic Transactions, electronic evidence in the form of electronic information or electronic documents shall be held as legitimate evidence as an extension or addition to the types of legal evidence in criminal procedural law in Indonesia while in cases outside of criminal acts Electronic Information and Transactions, the electronic evidence shall be located as evidence as in general criminal evidence but specifically in cases of special criminal acts such as criminal acts of corruption, evidence in the form of electronic information and electronic documents can be a source of obtaining evidence evidence.

B. Strength of Proof of Electronic Evidence Obtained Not in the Framework of Law Enforcement on the Request of Law Enforcement Officials After the Decision of the Constitutional Court No.20 / PUU-XIV / 2016.

The Indonesian Criminal Procedure Code (KUHAP) which has been in force since 1981 does not regulate the strength of electronic evidence in the process of proof at the trial. When electronic evidence presented by the public prosecutor at the hearing will invite debate about how the technical assessment of the electronic evidence.

Electronic evidence has a wide range and variety of types, and each type of electronic evidence has technical characteristics that require separate handling in determining legal validity. Therefore, there is a need for understanding among law enforcement officials regarding the principles of collecting, analyzing, and presenting various electronic evidence. In this case more specific regulations need to be established which can be used as guidelines in examining electronic evidence both at the level of investigation, prosecution and trial. The regulation or benchmark can be through the formation of regulations under the law, the interpretation of judges and legal findings (rechtsvinding) by judges. The regulation in question can also be in the form of a Government Regulation or it can also be a joint regulation between law enforcement agencies that can be used as a guideline both at the center and throughout the country. 
The absence of a law that regulates the technical evaluation of electronic evidence, the judge is expected to be able to determine the technical assessment of the strength of electronic evidence. In general criminal cases, provisions regarding electronic evidence have not been specifically regulated in the Criminal Procedure Code so that judges must make legal discoveries to prevent legal gaps because judges as law enforcement officers who have the authority to examine, hear and decide cases should not refuse the case submitted to him on the grounds The laws are incomplete or unclear ${ }^{8}$.

Judges as law enforcement officers who have the authority to make legal discoveries can interpret electronic evidence as an extension of letter evidence or instructions that are legitimate evidence according to Article 184 of the Criminal Procedure Code. When electronic evidence is stated by a judge as an extension of the evidence or instructions, then electronic evidence can be said to be valid evidence and can be presented at the hearing.

In assessing the validity of the electronic evidence presented at the trial, the judge refers to the statement of the expert to consider and guarantee the validity of the electronic evidence. The expert presented at the hearing is a person who has special expertise about the things needed to make a litigation of a criminal case for the purpose of examination, giving his opinion to the judge regarding the validity or absence of electronic evidence presented to the trial. When the expert states that the electronic evidence is valid, the judge can acknowledge that the evidence is legally accountable.

In the practice of proving in court there are differences of opinion regarding the strength of electronic evidence in proving criminal cases, one opinion assumes that the power of proof of electronic evidence in the form of electronic documents is the same as the evidence provided in Article 184 paragraph (1) letter c KUHAP on the grounds although electronic evidence is not regulated in the Criminal Procedure Code, electronic evidence in the form of electronic documents is basically an electronic letter, other than that electronic documents can be included in other letter categories that can only apply if they relate to the contents of other evidentiary instruments in accordance with Article 187 letter d KUHAP. So the strength of electronic evidence in the form of electronic documents is the same as the evidence of the letter stipulated in Article 184 paragraph (1) letter $\mathrm{c}$ of the Criminal Procedure Code, and the value of the evidentiary power depends on the judge's conviction.

Other opinions consider electronic evidence as a separate evidence which is the addition of existing types of evidence set out in Article 184 of the Criminal Procedure Code not as part of evidence that exists or cannot be compared to the letter as the first opinion. This second opinion is understandable because in the ITE Law states that electronic information and documents are an extension of legitimate evidence in accordance with procedural law, this can be seen in Article 5 paragraph (2) of the Electronic Information and Transaction Act while there is no a valid explanation of what is meant by the expansion so that the question arises whether the expansion is interpreted as the addition of evidence or is part of the existing evidence.

Apart from these differences of opinion, electronic evidence to be valid evidence must meet the formal and material requirements of electronic documents stipulated in Article 1 point 4, Article 5 paragraph (3), Article 6 and Article 7 of Information and Transaction Laws. Eelektronik is to have proof value, electronic information that is made, forwarded, sent, received or stored, which can be seen, displayed and / or heard through a computer or electronic system, including writing, voice, images and so on that have meaning or meaning understood by people who are able to understand it; declared valid if using / originating from an electronic system in accordance with the provisions stipulated in the law; considered valid if the information contained in it can be accessed, displayed, guaranteed integrity, and can be accounted for so as to explain a situation.

From these formal and material conditions it can be said that electronic documents in order to meet the minimum proof limit must be supported by information from experts who understand and can guarantee that the electronic system used to create, forward, transmit, receive or store electronic documents is in accordance with the provisions in Constitution; then also must be able to guarantee that these electronic documents remain in a state such as when they were made without any changes when

\footnotetext{
${ }^{8}$ Article 10 paragraph (1) of Law Number 48 of 2009 concerning Judicial Power.
} 
received by another party (integrity), that indeed the document originated from the person who made it (authenticity) and guaranteed not to be denied by the author (non repudiation).

Electronic evidence in the form of electronic documents when compared with the proof of the letter stipulated in Article Article 184 paragraph (1) letter $\mathrm{c}$ of the Criminal Procedure Code, it can be said that electronic documents have proof of quality as preliminary evidence, said as such because electronic documents cannot stand alone meet the minimum proof limit, therefore it must be assisted with one other proof. And the value of the proof power is left to the judge's conviction. In other words, electronic documents are still an ordinary evidence before the court, which still requires other evidence such as witness testimony to strengthen it.

Although so far the electronic evidence has been acknowledged as a legitimate piece of evidence, the value of the proof power has not yet had a perfect proof value or is still an ordinary proof. One of the steps that can be taken is that the judges and public prosecutors are not careless in utilizing the articles in the Information and Electronic Transaction Law and providing perfect proof value on the electronic evidence submitted is to make changes to the provisions of the Information Act and Electronic Transactions because there have been several decisions regarding the request for judicial review of articles in the Information and Electronic Transactions Act against the 1945 Constitution of the Republic of Indonesia to the Constitutional Court. One of them is the decision of the Constitutional Court Number 20 / PUU-XIV / 2016 dated September 7, 2016 which is a decision on the petition for testing article 5 paragraph (1) and paragraph (2) and Article 44 letter b of Law Number 11 Year 2008 concerning Information and Electronic Transactions, and Article 26A of Law Number 20 of 2001 concerning Amendments to Law Number 31 of 1999 concerning Eradication of Corruption Crimes against the Indonesian Constitution in 1945.

The decision of the Constitutional Court has become the basis for the Government to amend Law Number 11 of 2008 concerning Information and Electronic Transactions by ratifying Law Number 19 of 2016 concerning Amendments to Law Number 11 Year 2008 concerning Information and Electronic Transactions promulgated. on November 25, 2016.

The decision of the Constitutional Court Number 20 / PUU-XVI / 2016 according to the author has been very appropriate, especially the consideration of the assembly on how to obtain evidence in the criminal justice process, because it is not electronic evidence that should not be submitted in criminal justice processes if not taken by law enforcement, but the method of obtaining and submitting it is not permitted as evidence, if the electronic evidence is not submitted by law enforcers for law enforcement in the criminal justice process.

So that there are restrictions on how electronic evidence is obtained and who can submit electronic evidence as evidence in the criminal justice process considering that in Indonesia before the decision of the Constitutional Court Number 20 / PUU-XVI / 2016 there were no norms governing how to obtain and presenting evidence in the criminal justice process. The aim is to protect the privacy of someone who is a human right guaranteed by the constitution. If electronic evidence is obtained in ways that violate human rights and privacy, it cannot be justified because it is unlawful in legale evidence. Thus the legal objectives in the form of justice will be achieved which, according to Jeremy Bentham, is to realize the greatest happiness for the greatest number of people (the greatest happiness must be for the greatest number of people $)^{9}$. The goal of legislation according to Jeremy Bentham is to produce happiness for the community ${ }^{10}$. For him, goodness is kindness is happiness and evil is trouble. There is a close connection between good and evil. The duty of law is to preserve goodness and prevent evil. Strictly maintaining usability.

Usability is a benefit found in the theory of utilitarianism developed by Jeremy Bentham and his student John Stuard Mill. This theory is also called the greatest happiness theory. According to this theory

\footnotetext{
${ }^{9}$ Teguh Prasetyo dan Abdul Halim Barkatullah, Filsafat, Teori dan Ilmu Hukum, Raja Grafindo Persada, Jakarta, 2014, hlm.112.

10 Sukarno Aburarea, dkk, Filsafat Hukum, Teori dan Praktik, Kencana Prenada Grup, Jakarta, 2014, hlm.112
} 
an action is good if it brings benefits, but the benefits must involve not just one or two people but society as a whole ${ }^{11}$. Thus the making of a law must provide benefits for the happiness of the people and do not cause harm. It is fitting that there are laws that violate human rights. Judicial review of the 1945 Constitution of the Republic of Indonesia was submitted as Drs. Setya Novanto who submitted an application for judicial review of Article 5 paragraph (1) and paragraph (2) and Article 44 letter b of the Electronic Information and Transaction Law and Article 26A of the Corruption Act against the 1945 Constitution of the Republic of Indonesia which resulted in the decision of the Constitutional Court Number 20 / PUU-XVI / 2016 which provides protection for individual privacy from recording or illegal tapping so that there are restrictions on how to obtain and submit electronic evidence in the criminal justice process.

With the decision of the Constitutional Court Number 20 / PUU-XIV / 2016 dated September 7, 2016, in which one of the proposals, namely at table 1.2 states "Phrases" of Electronic Information and/or Electronic Documents "in Article 5 paragraph (1) and paragraph (2) and Article 44 letter b of Law Number 11 Year 2008 concerning Information and Electronic Transactions (State Gazette of the Republic of Indonesia Year 2008 Number 58, Supplement to the State Gazette of the Republic of Indonesia Number 4843) does not have binding legal force insofar as it is not interpreted specifically the phrase "Electronic Information and / or Electronic Documents "as evidence in the context of law enforcement at the request of the police, prosecutor's office and / or other law enforcement institutions stipulated by law as determined in Article 31 paragraph (3) of Law Number 11 Year 2008 concerning Information and Electronic Transactions. The purpose of the Constitutional Court's ruling is that electronic evidence in the form of electronic information and / or electronic documents to be valid evidence in criminal cases related to proof of non-criminal ITE or other criminal acts can be evidence or legal evidence the acquisition must be intended for law enforcement at the request of the police, prosecutor's office and / or other law enforcement institutions such as the Corruption Eradication Commission and others, which are stipulated by laws and regulations. Apart from that, electronic evidence cannot be valid evidence and do not have the power of proof.

For example in the case of a criminal act of premeditated murder with the defendant Jessica Kumala aka Jessica Kumala Wongso aka Jess who was indicted by the public prosecutor on charges of violating Article 340 of the Criminal Code and has been decided by the Central Jakarta District Court with the decision number: 777 / Pid.B / 2016 / PN .JKT.PST dated October 27, 2016, among the evidence submitted by the public prosecutor at the trial in the form of 1 (one) gray 32 GB Flashdisk unit S / N 1430A7A412CAT containing CCTV footage from Restaurant Olivier West Mall Grand Indonesia and 1 (one ) WD Brand External Hard Drive unit My Passport Ultra 500GB black. Based on the facts revealed at the hearing from the testimony of witnesses of Restaurant Olivier West Mall Grand Indonesia CCTV cameras installed by the owner of Restaurant Olivier West Mall Grand Indonesia in which there were records of the death of Mirna Salihin victims not intended for law enforcement at the request of the authorized law enforcement . The CCTV camera in the cafe Restaurant Olivier West Mall Grand Indonesia is a camera that is installed in a public place (public area) intended to record all the activities of customers and employees in the cafe. If based on the ruling of the Constitutional Court, then electronic evidence in the form of electronic information in the form of CCTV camera footage is not valid as evidence and does not have the power of proof. However, the Central Jakarta District Court Judges in their legal considerations still received evidence in the form of 1 (one) gray 32 GB Flashdisk unit S / N 1430A7A412CAT containing CCTV footage from Restaurant Olivier West Mall Grand Indonesia as valid evidence and information electronics in the form of CCTV footage is one of the bases in legal considerations.

In the Decision of the Central Jakarta District Court Number: 777 / Pid.B / 2016 / PN.JKT.PST dated October 27, 2016, related to CCTV footage which is used as evidence by the Public Prosecutor, the consideration of the Panel of Judges of the Central Jakarta District Court is as follows ${ }^{12}$ :

\footnotetext{
${ }^{11}$ Zainal Asikin, Mengenal Filsafat Hukum, Pustaka Reka Cipta, Bandung, 2013, hlm. 117.

${ }^{12}$ Decision of the Central Jakarta District Court Number: 777 / Pid.B / 2016 / PN.JKT.PST.
} 
"Considering, as well as the CCTV footage questioned by the Defendant's Legal Advisor is not worthy of being used as evidence in this trial, the Panel of Judges argued that CCTV in the cafe was not intentionally intended for cases in this case, but in general it had previously been installed in that place that can monitor every incident that occurs in the Olivier cafe environment so that the CCTV does not have to be made by the authorized Actor while regarding the alleged occurrence of tempering / insertion on the 86 video or on the CCTV image, the digital experts have sworn at the trial. If the Defendant's Legal Counsel is able to prove in the future that there is a lie for the opinion of the Experts, they can use legal means in accordance with Article 242 of the Criminal Code concerning the giving of false information.

Considering, that based on these considerations, the Panel of Judges argued the extent to which the CCTV footage was relevant to the event that described the same person, related to empirical facts is the same, especially digital electronic devices in judicial practice have often been used by judges in revealing the truth of the facts, then the CCTV recording can be used as an extension of Article 184 paragraph (1) of the Criminal Procedure Code as "Evidence Goods" which, if in accordance with the facts and criminal events, can be used as a panel of judges to ensure criminal events. This is reinforced by the Law No. 11 of 2008 concerning Information and Electronic Transactions.

The decision of the Central Jakarta District Court was appealed by the Jakarta Capital City High Court in the decision of the Jakarta Capital City High Court Number 393 / PID / 2016 / PT.DKI on March 7, 2017 and subsequently the Indonesian Supreme Court in its appeal number: 498K / Pid / 2017 dated June 21, 2017 stated that they rejected the cassation request from the Cassation Appellant Jessica Kumala aka Jessica Kumala Wongso.

The problems that arise related to electronic evidence, especially CCTV footage, after the decision of the Constitutional Court Number 20/PUU-XIV/2016 dated September 7, 2016 are whether what is meant by the phrase "at the request" of the police, prosecutors or other law enforcement above is the request for installation / recording using CCTV or requesting CCTV camera footage. This becomes something debatable. If what is intended is the request for recording / installation of CCTV cameras, then the entire installation of CCTV cameras in public places such as malls, supermarkets, minimarkets, mosques, highways, ATM machines, housing complexes, government agencies and others must be at the request of the police, prosecutors and / or other law enforcers if later it will be used as evidence or legal evidence at a court hearing. But if what is intended is a request for the recording, so long as it is carried out in the context of law enforcement and according to the procedure, CCTV camera recordings can be used as evidence or legitimate evidence in a court hearing.

Actually it becomes something strange and exceeds the limit when the Constitutional Court as an institution that functions as a guardian of the constitution (Guardian of Contitusion) which maintains the stability of laws and regulations by the authority to cancel laws that are not in accordance with the 1945 Constitution which is referred to as Negative Legislature instead became a Positive Legislature, which added the norm in the form of a new procedure which would be a dilemma for law enforcement in disclosing criminal cases related to the power of proof of electronic evidence. The decision of the Constitutional Court Number 20 / PUU-XIV / 2016 contained a very very good purpose, but on the other hand it added a new burden for every Indonesian citizen to protect his interests from other parties who did evil, because it was limited by amar in the decision of the Constitutional Court by having to ask permission from law enforcement officials, both the police, prosecutors or other law enforcement agencies to install electronic security equipment, because when the procedure is not carried out, then it becomes a waste because the results become invalid as evidence or evidence in the trial.

In other cases such as electronic evidence in the form of conversational recordings in a case known as "Papa Minta Shares" which was the first evidence of an investigation into the alleged trial of conspiracy to commit a criminal act of corruption by the Attorney General's Office of Drs. Setya Novanto is whether or not it can be used as evidence, this question becomes relevant after the decision of the Constitutional Court Number 20 / PUU-XVI / 2016 dated September 2016. The question is important in the case of "Papa Minta Shares" the initial evidence on which the warrant was issued the investigation by the Attorney General's Office is a recording of the conversation between Drs. Setya Novanto together 
with M. Rizal Chalid and PT Freeport Indonesia's President Director Syamsuddin Maaruf who were secretly carried out by Syamsudiin Maaruf, not by law enforcement.

Electronic information and/or electronic documents basically cannot be valid evidence, because based on their nature they are evidence. In the practice of criminal proceedings other than the criminal acts of Information and Electronic Transactions in the court, not electronic information / documents that are valid evidence in the trial, but expert information in the Minutes of Expert examination appointed by the investigator on electronic information and / or electronic documents which will be a valid proof.

Departing from the understanding that electronic information/documents are not evidence in cases other than criminal acts of Information and Electronic Transactions but only as evidence, they will also affect the validity of the procedure for obtaining recordings in the case of "asking for shares". The recording is not made by law enforcers, but by individuals, thus the record is the property of the individual. In this case, to assess whether the record can have proof value as evidence, it is not reviewed from the regulations concerning procedures or wiretapping procedures that have not been regulated in the Criminal Procedure Code, but must be reviewed from the regulations regarding seizures as stipulated in Article 38 to Article 46 of the Criminal Procedure Code. If the investigator or investigator obtains a recording in the case of "father asking for shares" from the hands of Syamsuddin Maaruf in accordance with the provisions of the confiscation in the Criminal Procedure Code, the seizure is valid, and the record is valid as evidence. Furthermore, of course the substance of the evidence needs to be examined according to the procedures for examining electronic evidence.

With the issuance of Law Number 19 of 2016 concerning Amendment to Law Number 11 of 2008 concerning Electronic Information and Transactions, electronic evidence in the form of electronic information or electronic documents can be used as valid evidence or at least evidence in the trial the court insofar as the retrieval and / or transfer of electronic evidence (cloning process) is carried out according to the procedure, complete with the minutes of retrieval/transfer, carried out by the competent authorities, electronic information and electronic documents can be accessed, displayed, guaranteed integrity, can be accounted for and enforced law at the request of the police, prosecutor's office and / or other law enforcement institutions stipulated by law.

\section{Conclusions and Recommendations}

\section{Conclusion}

a. The position of electronic evidence after the entry into force of the Law on Information and Electronic Transactions and its amendments to Law Number 19 Year 2016 concerning Amendments to Law Number 11 Year 2008 concerning Information and Electronic Transactions, in cases of criminal acts of Information and Electronic Transactions is as separate evidence, namely electronic evidence which is an extension of the type of legal evidence stipulated in the Criminal Procedure Code while in cases other than criminal acts of Information and Electronic Transactions, electronic evidence is only located as evidence.

b. The strength of evidence from electronic evidence obtained is not in the context of law enforcement at the request of law enforcement officials in the criminal justice post of the Constitutional Court ruling No. 20 / PUU-XIV / 2016 is not having the power of proof both as evidence and evidence except electronic evidence that is public.

\section{Recommendation}

a. The government is expected to immediately reform the Criminal Procedure Law which can accommodate the development of electronic evidence along with advances in technology and information to meet practical needs and realize legal certainty by revising and ratifying 
the draft Criminal Procedure Code that has set up electronic evidence as evidence and put it on the agenda national legislation program so as to realize the unification of criminal procedural law.

With regard to the absence of provisions in the laws and regulations that regulate the strength of electronic evidence in proving criminal cases, the author recommends that judges as law enforcement officers who have the authority to examine, hear and decide criminal cases to conduct legal findings fairly and objectively follow developments in society.

\section{References}

Adami Chazawi \& Ardi Ferdian. (2015). Tindak Pidana Informasi dan Transaksi Elektronik, Media Nusa Creative, Malang.

Amirudin \& Zainal Asikin. (2014). Pengantar Metode Penelitian Hukum, Raja Grafindo Persada, Jakarta, cetakan ke-8.

Lilik Mulyadi. (2008). Bunga Rampai Hukum Pidana Perspektif, Teoritis dan Praktik, Alumni, Bandung.

Munir Fuady. (2012).Teori Hukum Pembuktian, Citra Adiyta Bakti, Bandung.

Sigid Suseno. (2012).Yurisdiksi Tindak Pidana Siber, Refika Aditama, Bandung, Cetakan I.

Sukarno Aburarea. (2014). dkk, Filsafat Hukum, Teori dan Praktik, Kencana Prenada Grup, Jakarta.

Teguh Prasetyo dan Abdul Halim Barkatullah. (2014).Filsafat, Teori dan Ilmu Hukum, Raja Grafindo Persada, Jakarta, 2014.

Zainal Asikin. (2013). Mengenal Filsafat Hukum, Pustaka Reka Cipta, Bandung, 2013.

Article 10 paragraph (1) of Law Number 48 of 2009 concerning Judicial Power.

Decision of the Central Jakarta District Court Number: 777 / Pid.B / 2016 / PN.JKT.PST.

Decision of the Constitutional Court Number: 20 / PUU-XIV / 2016 dated 7 September 2016 pages 97-98.

Law Number 8 of 1981 concerning Criminal Procedure Law.

\section{Copyrights}

Copyright for this article is retained by the author(s), with first publication rights granted to the journal. This is an open-access article distributed under the terms and conditions of the Creative Commons Attribution license (http://creativecommons.org/licenses/by/4.0/). 